\title{
Phytoprotection
}

\section{Fusarium head blight : a re-emerging disease}

\section{T.C. Paulitz}

Volume 80, numéro 2, 1999

URI : https://id.erudit.org/iderudit/706188ar

DOI : https://doi.org/10.7202/706188ar

Aller au sommaire du numéro

Éditeur(s)

Société de protection des plantes du Québec (SPPQ)l

ISSN

0031-9511 (imprimé)

1710-1603 (numérique)

Découvrir la revue

Citer cet article

Paulitz, T. (1999). Fusarium head blight : a re-emerging disease. Phytoprotection, 80(2), 127-133. https://doi.org/10.7202/706188ar d'utilisation que vous pouvez consulter en ligne.

https://apropos.erudit.org/fr/usagers/politique-dutilisation/ 


\author{
Colloque / Colloquium - Saint-Jean-sur-Richelieu (Québec), Canada \\ 9 juin / 9 June 1999 \\ Nouveaux problèmes de phytoprotection au Québec / \\ New plant protection problems in Quebec
}

\title{
Fusarium head blight: a re-emerging disease
}

\author{
Timothy C. Paulitz \\ Dept. of Plant Science, McGill University, 21111 Lakeshore, Ste. Anne de Bellevue, \\ Quebec, Canada H9X 3 V9
}

\section{PHYTOPROTECTION 80: 127-133}

Fusarium head blight (scab) of wheat is endemic in Eastern Canada and is considered to be one of the most important disease on this crop, in terms of the potential losses and harm to consumers. The disease is caused by Fusarium graminearum Schwabe [teleomorph = Gibberella zeae (Schwein.) Petch]. The same pathogen also attacks other small grains such as oats and barley; and causes an ear rot of maize. The epidemiology of this disease have been reviewed by Sutton (1982) and Parry et al. (1995). This pathogen survives over the winter on wheat and maize debris. The following spring, purple-black perithecia are formed. These are the fruiting bodies of the sexual stage of the fungus, Gibberella zeae. Asci and 4celled ascospores are formed and forcibly ejected around the time of anthesis of the wheat crop. In Quebec, anthesis of spring wheat occurs in late June to early July and this is when the wheat is most susceptible to this pathogen. Ascospores are considered to be the most important primary inoculum of this disease in eastern North America. These ascopores are deposited on the heads of wheat, germinate, and infect into the developing seed. Compounds in the anthers such as choline and betaine are thought to stimulate the germination of the spores (Strange et al. 1978). After infection, the fungus continues to spread to the spikelets, glumes, and rachis of the head. Two to three weeks after anthesis, the first symptoms appear. Infected spikelets turn brown and sporodochia form on the glumes. These orange-pink colored sporodochia contain masses of three to seven septate macroconidia of $F$. graminearum, and may cause infection on secondary tillers that flower later. However, the disease is considered to be monocyclic, since the secondary inoculum is formed when the susceptibility of the host is low, and there is little plant to plant spread from this inoculum. At harvest, seeds infected at anthesis are small, whitish colored, and wrinkled. Other seeds can also be infected, although they have a normal appearance. The infected debris is often left on the ground over the winter, especially in no-till or reduced tillage situations. Perithecia can also form in the fall, although it is unclear what role they play in the epidemiology of the disease the following spring. $G$. zeae is homothallic, meaning it can form the sexual stage by selfing. PCR-RAPD markers and vegetable compatibility group studies show a large amount of genetic diversity among strains (Dusabenyagasani et al. 1999; Bowden and Leslie 1992). Perithecia are readily formed in culture and in the field in areas with adequate summer rainfall, such as eastern Canada. The pathogen

Note du rédacteur : le texte ci-dessus est présenté tel que soumis / Editor's note : the above text is presented as submitted. 
has also been divided into two ecotypes, Group I and II. Group I is found in arid areas such as Australia and Eastern Washington and primarily causes root, seedling, and stalk rots. It does not form the sexual stage in culture or in nature, and thus does not attack the head. Group I has recently been reclassified as a new species F. pseudograminearum, based on molecular evidence and subtle differences in the septation of the macroconidia (Aoki and O’Donnell 1999).

Why is this disease so important? Because the fungus produces mycotoxins in the grain which can harm animals and humans. The two most important are deoxynivalenol (DON, vomitoxin) and zearalenone. A number of other trichothecenes can also be formed. This subject is reviewed in a book by Miller and Trenholm (1994). DON causes feeding refusal in animals, especially nonruminant swine. Zearalenone is an estrogen-like compound that causes reproductive disorders in swine. At the present time, the maximum allowable limit of DON in grain in Canada is 1 ppm for human consumption, 2 ppm for animal consumption. Levels in the grain are heavily monitored by elevators, millers, and government agencies both in Canada and the United States.

Why is this called a re-emerging disease? It is already endemic on wheat and corn in eastern Canada, because of the high probability of rain during the susceptible period of anthesis. For example, in 1996, $85 \%$ of the winter wheat crop of southern Ontario was destroyed by the disease, resulting in losses of over \$100 million (Schaafsma et al. 1998) During anthesis, rain showers came in off of Lake Ontario and set the stage for the epidemic. Obviously, there was adequate inoculum present, even though the growers practiced strip rotation with soybeans and corn. A major epidemic on maize also occurred in 1990 (Charmley et al. 1994). However, Quebec and eastern Ontario are minor producers of wheat, compared to the upper Midwest of the US and prairie provinces. Most of the vwheat in Quebec is grown for animal feed and production has declined over the last
10 years, being replaced by corn and soybeans. In the main wheat growing areas of the mid continent, Fusarium head blight was considered to be a minor problem, surpassed by foliar diseases such as rust and Septoria. But in 1993, an epidemic swept through these areas and has continued for the last 6 years. This disease has caused over three billion dollars US in losses and is considered to be the most costly plant disease epidemic of the last half of the 20th century. This subject has been reviewed by Bai and Shaner (1994) and McMullen et al. (1997). The impact of this disease, along with the low grain prices of the last 2 years, has lead to numerous foreclosures of farms in Minnesota, North Dakota, Manitoba and Saskatchewan. There is also concern that the disease is moving to dryer areas of Alberta and Saskatchewan, where it has not been previously a problem (Gilbert 1998).

Why has the disease re-emerged as a problem in these areas? One reason is the increased summer precipitation that these areas have received since 1993. Some areas have received double their normal summer rainfall. Like most diseases, free water or moisture is needed for infection. Secondly, the prevalence of no-till and low-till agriculture over the last $15-20$ years has increased the inoculum load of the fungus. The adoption of this technology has been widespread, and has several intrinsic benefits, such as reduction in soil erosion and reduced energy and labor costs. However, since much of the residue is left on the surface, the inoculum can overwinter. Many studies have shown a reduction in survival of the pathogen if the residue is buried (Khonga and Sutton 1988; Teich and Hamilton 1985). However a return to the moldboard plow is unlikely. There may have also been a loss of genetic resistance in modern cultivars, since they were not selected against this disease. At the present time, cultivars are moderately to highly susceptible. Finally, there has been some speculation that the disease has increased because of the movement of corn production westward into new areas previously cropped with wheat. This pathogen 
attacks both corn and wheat, so this may lead to a buildup of inoculum.

\section{MANAGEMENT STRATEGIES}

How can this devastating disease be managed or controlled? There are a number of different strategies, however as consistent with the principles of integrated pest management (IPM), none alone will be sufficient to provide a consistent and stable reduction of this disease.

\section{Resistant cultivars}

In the long term, this is the most economically and environmentally feasible method of managing this disease. At present, most of the commercial cultivars are moderately to highly susceptible. However, since 1993, huge efforts have been put into finding resistance. Most of the work has been to incorporate resistance from Chinese lines such as Sumai 3 and Ning or from the Brazilian line Frontana (Dubin et al. 1997). Resistance can be expressed in a number of ways. Type I resistance is resistance to initial infection, Type II is resistance to spread of the hyphae within the host, and type III is resistance to kernel symptoms, or the genetic ability of wheat to degrade DON (Mesterházy 1995). Resistance is quantitative and may involve 3-5 genes. A number of groups are attempting to map the resistance genes with the goal of using marker assisted selection to speed up the breeding process (Anderson et al. 1998). Other groups are attempting to transform wheat plants using biolistic techniques to insert genes for PR proteins such as thaumatin-like proteins into wheat plants (Skadsen et al. 1998).

\section{Cultural practices}

Since the pathogen survives on the crop debris, burying the debris results in faster decomposition than if the debris is left on the soil (Dill-Macky et al. 1998; Khonga and Sutton 1988; Teich and Hamilton 1985). Therefore, cultural practices such as conventional tillage may reduce disease, compared to low till. However, conventional tillage is not likely to be widely practiced because of the energy costs, degradation of soil structure and erosion. In addition, if inoculum can travel a long distance, as suggested by Francl et al. (1999) who trapped spores at sites remote from fields, then tillage may not have a significant effect. Crop rotation is another cultural practice that could reduce disease. The recommendation is not to plant wheat where the previous crop was corn or wheat (Martin and Johnston 1982), since wheat following corn has higher levels of disease (Teich and Nelson 1984), and soybean-corn rotation gave less disease than corn-corn (Lipps and Deep 1991).

\section{Chemical control}

Chemical control is another option, but until recently, most of the fungicides gave only moderate control (Mesterházy 1995). These products have to be applied to the heads to protect against infection. However, new classes of fungicides such as tebuconazole (Folicur) and propiconazole (Tilt) have given better performance (Mesterházy and Barlok 1996; McMullen 1998) In 1998 and 1999, Folicur was given an emergency registration in the US on wheat and barley with a pre-harvest interval of 30 days. Tilt has full registration in the US up through early flag leaf emergence, but certain states have labels to apply through heading. In 1998 and 1999, approximately 1 million acres were treated in North Dakota and Minnesota (Marcia McMullen, personal communication). In 1998 and 1999, fungicide trials were conducted in both Ontario and Quebec, with the purpose of obtaining registration in Canada. However, the economic cost and environmental concerns may limit the use of this strategy. In addition, new spray technologies must be developed, since existing techniques are geared toward coverage of leaves, not a vertically placed head.

\section{Biological control}

Biological control of this disease is still in its infancy. There are three strategies for biological control of this disease. The first is to apply the bioprotectant to the seed, to prevent seedling infection (Huang and Wong 1998). The 
second strategy, also protectant, is to apply bacteria, yeasts, or fungi to the head of wheat at the time of flowering, when it is most susceptible. For example, Sporobolomyces roseus and Paenibacillus macerans suppressed infection of wheat when applied in the greenhouse (Stockwell et al. 1997). A recent program is selecting bacteria for their ability to utilize choline, a component of pollen that stimulates the germination of Fusarium graminearum, with the idea that these bacteria will compete with the fungus for these compounds (Khan et al. 1998). This strategy has several obstacles, among which are survival of the microorganisms on the head in the field, obtaining complete coverage, and the timing of application (da Luz et al. 1999). F. graminearum can infect after anthesis, although the susceptibility is lower, thus one application of the biocontrol agent may not be sufficient. The third strategy is to apply biocontrol agents to the crop residue, to decompose the debris and interfere with the production of perithecia in the debris. However, little work has been done in this area. Fernandez (1992) showed that inoculation of wheat straw with Trichoderma harzianum reduced the incidence of colonization of Fusarium graminearum, but no measure was made of severity of colonization or effect on inoculum production. This strategy has been successful with interfering with the overwintering and primary inoculum production of V'enturia inaequalis, an Ascomycete that overwinters in apple leaves (Carisse et al. 1999; Heye and Andrews 1983). Microsphaeropsis sp., the Coelomycete used in the study by Carisse et al. (1999), is also being tested as a biocontrol agent against $G$. zeae, both in the field and lab (Bujold et al. 1999). It has been applied in the fall and spring to the residue of field microplots that were inoculated with macroconidia at the flowering stage and has changed the dynamics and timing of perithecia formation (Bujold, Carisse, and Paulitz, unpublished). Another possibility is to apply nutrients to hasten the decomposition of the debris. Khonga and Sutton (1991) found that urea, acetic acid and propionic acid inhibited the formation of perithecia on artificially infested corn stems.

\section{EPIDEMIOLOGY OF FUSARIUM HEAD BLIGHT CAUSED BY THE SEXUAL STAGE GIBBERELLA ZEAE}

In the past 8-9 years, my laboratory has been investigating the epidemiology of this disease in Quebec. This research was possible because of the development of a method to produce ascospore inoculum in the field which mimicked natural inoculum. Corn kernels are soaked in water, placed in glass jars or aluminum pans, autoclaved twice, and inoculated with macroconidia of $F$. graminearum. After 3 weeks, the corn kernels are colonized with mycelium, are dried and spread on the ground in field plots of wheat. After 10-14 days, perithecia are formed and ascospores are ejected. This enabled us to look at questions such as : When are ascospores released during the day and season? What environmental conditions are associated with ascospore release? How far can inoculum be dispersed? What do disease foci and gradients look like? When is wheat most susceptible to infection?

Ascospores are primarily released, beginning in the early evening, around 16:00-20:00 (Paulitz 1996). Release begins around the same time as the relative humidity in the canopy increases as the temperature decreases. This could be coincidental, or it could mean that asci must dry out during the day, and re-hydrate in the evening by taking up moisture from the air, leading to swelling and bursting of the asci or ascus attachment in the perithecia. Ascospores are released on days without rainfall, contrary to other reports that say rainfall is required for release. In fact, on wet days, we did not see ascospore release. Ascospores were typically released 2-4 days after a major rain event, indicating the importance of moisture in the maturation of the perithecia and asci, but not their release. This same timing has been corroborated in other subsequent studies. Disease from small area sources of inoculum $\left(1 \mathrm{~m}^{2}\right)$ are asymmetrical, steeper on the upwind than downwind side of the gradient (Fernando et al. 1997b). 
The direction of the gradient corresponds to the nightly wind direction. Disease gradients were derived from these foci, using exponential models. The $D_{50}$, the distance at which disease declines $50 \%$ from the source, was $5-10$ $\mathrm{m}$, and the $D_{90}$ value (distance at which disease declines $90 \%$ ) was between 10 $25 \mathrm{~m}$. However, more recent experiments with spore gradients from larger sources of overwintered inoculum suggests that the gradients may be longer declining only $50 \% \quad 20-40 \mathrm{~m}$ from the source (Bujold, Carisse, and Paulitz, unpublished). Experiments are currently underway this year, using longer transects of rotorod samplers $(50 \mathrm{~m})$ and $10 \mathrm{~m} \times 10 \mathrm{~m}$ sources of overwintered inoculum. Studies with potted wheat plants of different ages exposed to inoculum in the field showed that anthesis-milk stage is most susceptible, but seed infection can take place from late milk through soft and hard dough stage (Fernando et al. 1997a). These results were corroborated in experiments with field plants whose heads were agged before emergence and exposed at various stages of maturity. Current research is dealing with the dynamics of perithecia formation. We found two cycles of perithecia formation in 1997-1998 and 1998-1999. Because of the abnormally warm fall and late snowfall in these two years, mature perithecia were formed in September and October. The mature ascospores were still viable in December, although they took on an abnormal morphology. Instead of being straightwalled, the ascospores were constricted at the septa, and many of them had fragmented. However, the fragments were still viable and capable of germination. The role of perithecia and ascospores formed in the fall is still unknown. Although the asci were degraded by late fall, ascospores could still be splashed dispersed the following in spring and colonize further debris. The following May, over $70 \%$ of the overwintered ascospores were still viable. Another crop of new perithecia formed in late May - early June. At the same time, we have been recording temperature and moisture in debris over the entire season, which may lead to predictive models based on threshold degree days and hours of critical wetness. The hope is that growers may be able to predict risk by knowing when perithecial maturity will occur and when ascosores will be released, relative to the flowering of the crop.

\section{REFERENCES}

Anderson, J.A., B.L. Waldron, B. MorenoSevilla, R.W. Stack, and R.C. Frohberg. 1998. DNA markers for Fusarium head blight resistance QTL in two wheat populations. Page 57 in Proceedings of the 1998 National Fusarium Head Blight Forum, Michigan State Univ, East Lansing, Mich. October 1998.

Aoki, T., and K. O'Donnell. 1999. Morphological and molecular characterization of Fusarium pseudograminearum sp. nov., formerly recognized as the Group I population of Fusarium graminearum. Mycologia 91 : 597-609.

Bai, G., and G. Shaner. 1994. Scab of wheat : prospects for control. Plant Dis. 78 : 760766.

Bowden, R.L., and J.F. Leslie. 1992. Nitratenonutilizing mutants of Gibberella zeae (Fusarium graminearum) and their use in determining vegetative compatibility. Exp. Mycol. 16 : 308-315.

Bujold, I., T.C. Paulitz, M. Tremblay, and 0. Carisse. 1999. Optimization of in vitro perithecial production of Gibberella zeae on wheat and corn debris. Phytopathology 89 : S10 (abstract).

Carisse, O., V. Philion, D. Rolland, and J. Bernier. 1999. Effect of fall application of fungal antagonists on spring ascospore production of the apple scab pathogen, Venturia inaequalis. Phytopathology (in press).

Charmley, L.L., A. Rosenberg, and H.L. Trenholm. 1994. Factors responsible for economic losses due to Fusarium mycotoxin contamination of grains, foods and feedstuffs. Pages 471-486 in J.D. Miller, and H.L. Trenholm (eds.), Mycotoxins in grain : compounds other than aflatoxin, Eagan Press, St. Paul, MN.

da Luz, W.C., C.A. Stockwell, and G.C. Bergstrom. 1999. Present status and theoretical aspects of biological control of Fusarium graminearum. In K. Leonard and W. Bushnell (eds.), Fusarium head blight of wheat and barley, American Phytopathological Society Press, St. Paul, MN. (in press). 
Dill-Macky, R., A.L. Sims, and S.A. Pereyra 1998. Survival of Fusarium graminearum in wheat residue. Pages 41-43 in Proceedings of the 1998 National Fusarium Head Blight Forum, Michigan State Univ. October 1998.

Dubin, H.J., L. Gilchrist, J. Reeves, and A McNab. 1997. Fusarium head scab : global status and future prospects. Mexico, D. F. CIMMYT.

Dusabenyagasani, M., D. Dostaler, and R.C. Hamelin. 1999. Genetic diversity among Fusarium graminearum strains from Ontario and Quebec. Can. J. Plant Pathol. $22: 308-314$

Fernandez, M.R. 1992. The effect of Trichoderma harzianum on fungal pathogens infesting wheat and black oat straw. Soil Biol. Biochem. 24 : 1031-1034.

Fernando, W.G.D., T.C. Paulitz, W.L. Seaman, and R.A. Martin. 1997a. Fusarium head blight susceptibility of wheat inoculated at different growth stages. Phytopathology 87 : S30 (abstract).

Fernando, W.G.D., T.C. Paulitz, W.L. Seaman, P. Dutilleul, and J.D. Miller. 1997b. Head blight gradients caused by Gibberella zeae from area sources of inoculum in wheat field plots. Phytopathology 87 : 414-421.

Francl, L., G. Shaner, G. Bergstrom, J. Gilbert, W. Pedersen, R. Dill-IMacky, L. Sweets, B. Corwin, Y. Jin, D. Gallenberg, and J. Wiersma. 1999. Daily inoculum levels of Gibberella zeae on wheat spikes Plant Dis. 83 : 667-674.

Gilbert, J. 1998. Fusarium head blight in Canada in 1998. Page 107 in Proceedings of the 1998 National Fusarium Head Blight Forum, Michigan State Univ. October 1998.

Heye, C. C., and J.H. Andrews. 1983. Antagonism of Athelia bombacina and Chaetomium globosum to the apple scab pathogen, Venturia inaequalis. Phytopathology $73: 659-654$.

Huang, Y., and P.T.W. Wong. 19!98. Effect of Burkholderia (Pseudomonas) cepacia and soil type on the control of crown rot in wheat. Plant Soil $203: 103-108$.

Khan, N.I., D.A. Schisler, M.J. Boehm, P.E. Lipps, P.J. Slininger, and R.J. Bothast. 1998. Biological control of scab of wheat incited by Gibberella zeae. Pages 45-46 in Proceedings of the 1998 National Fusarium Head Blight Forum, Michigan State Univ. October 1998.

Khonga, E.B., and J.C. Sutton. 1988. Inoculation, production and survival of Gibberella zeae in maize and wheat residues. Can. J. Plant Pathol. 10 : 232-239.
Khonga, E.B., and J.C. Sutton. 1991. Effects of acetic acid, propionic acid and urea on inoculum production by Gibberella zeae in maize and wheat residues. Mycol. Res. 95 : 409-412.

Lipps, P.E., and I.W. Deep. 1991. Influence of tillage and crop rotation of yield, stalk rot and recovery of Fusarium and Trichoderma spp. from corn. Plant Dis. 75 : 828-833.

Martin, R.A., and H.W. Johnston. 1982. Effects and control of Fusarium disease of cereal grains in the Atlantic provinces. Can. J. Plant Pathol. 4 : 210-216.

McMullen, M. 1998. Fungicide technology network of the national FHB initiative. 1998 report. Page 47 in Proceedings of the 1998 National Fusarium Head Blight Forum, Michigan State Univ. East Lansing, Mich. October 1998.

McMullen, M.P., R. Jones, and D. Gallenberg. 1997. Scab of wheat and barley : a re-emerging disease of devastating impact. Plant Dis. 81 : 1340-1348.

Mesterházy, A. 1995. Types and components of resistance against Fusarium head blight of wheat. Plant Breeding $114: 377$ 386.

Mesterházy, A., and T. Barlok. 1996. Control of Fusarium head blight of wheat by fungicides and its effect on the toxin contamination of grains. PflanzenschutzNachri. Bayer 49 : 181-198.

Miller, J.D., and H.L. Trenholm. (eds). 1994 Mycotoxins in grain : compounds other than aflatoxin. Eagan Press, St. Paul, MN.

Parry, D.W., P. Jenkinson, and L. McLeod. 1995. Fusarium ear blight (scab) in small grain cereals - a review. Plant Pathol. 44 : 207-238

Paulitz, T.C. 1996. Diurnal releases of ascospores by Gibberella zeae in inoculated wheat plots. Plant Dis. 80 : 674-678.

Schaafsma, A.W., L. Tamburic-Iliniic, and J.D. Miller. 1998. The effect of agronomic practice on the accumulation of deoxynivalenol (DON) in winter wheat fields in Ontario, 1996-1997. Pages 7-9 in Proceedings of the 1998 National Fusarium Head Blight Forum, Michigan State Univ. October 1998.

Skadsen, R.W., A.M. Nuutila, P. Sathish, and H.K. Kaeppler. 1998. Transformation of barley with antifungal genes and strategies for their targeted expression. Pages 93-95 in Proceedings of the 1998 National Fusarium Head Blight Forum, Michigan State Univ. October 1998. 
Stockwell, C.A., W.C. Luz, and G.C. Bergstrom. 1997. Biocontrol of wheat scab with microbial antagonists. Phytopathology. 87 : S94 (abstract).

Strange, R.N., A. Deramo, and H. Smith. 1978. Virulence enhancement of Fusarium graminearum by choline and betaine and of Botrytis cinerea by other constituents of wheat germ. Trans. Br. Mycol. Soc. $70: 201-207$.

Sutton, J.C. 1982. Epidemiology of wheat head blight and maize ear rot caused by Fusarium graminearum. Can. J. Plant Pathol. 4 : 195-209.
Teich, A.H., and J.R. Hamilton. 1985. Effect of cultural practices, soil phosphorus, potassium, and $\mathrm{pH}$ on the incidence of Fusarium head blight and deoxynivalenol levels in wheat. Appl. Env. Microbiol. 49 : 1429-1431.

Teich, A.H., and K. Nelson. 1984. Survey of fusarium head blight and possible effects of cultural practices in wheat fields in Lambton County in 1983. Can. Plant Dis. Surv. $64: 11-13$. 